\title{
Comparability of Microarray Data between Amplified and Non Amplified RNA in Colorectal Carcinoma
}

\author{
Roland S. Croner, ${ }^{1}$ Berthold Lausen, ${ }^{2}$ Vera Schellerer, ${ }^{1}$ Isabel Zeittraeger, ${ }^{3}$ Axel Wein, ${ }^{3}$ \\ Claus Schildberg, ${ }^{1}$ Thomas Papadopoulos, ${ }^{4}$ Arno Dimmler, ${ }^{4}$ Eckhart G. Hahn, ${ }^{3}$ \\ Werner Hohenberger, ${ }^{1}$ and Wolfgang M. Brueckl ${ }^{3}$ \\ ${ }^{1}$ Department of Surgery, Friedrich-Alexander University, Erlangen-Nuremberg, Krankenhausstrasse 12, 91054 Erlangen, Germany \\ ${ }^{2}$ Department of Mathematical Sciences, University of Essex, Wivenhoe Park, Colchester CO4 3SQ, UK \\ ${ }^{3}$ Department of Medicine 1, Friedrich-Alexander University, Erlangen-Nuremberg, Ulmenweg 18, 91054 Erlangen, Germany \\ ${ }^{4}$ Department of Pathology, Friedrich-Alexander University, Erlangen-Nuremberg, Krankenhausstrasse 12, 91054 Erlangen, Germany
}

Correspondence should be addressed to Roland S. Croner, roland.croner@uk-erlangen.de

Received 19 February 2009; Revised 28 May 2009; Accepted 13 July 2009

Recommended by Yataro Daigo

Microarray analysis reaches increasing popularity during the investigation of prognostic gene clusters in oncology. The standardisation of technical procedures will be essential to compare various datasets produced by different research groups. In several projects the amount of available tissue is limited. In such cases the preamplification of RNA might be necessary prior to microarray hybridisation. To evaluate the comparability of microarray results generated either by amplified or non amplified RNA we isolated RNA from colorectal cancer samples (stage UICC IV) following tumour tissue enrichment by macroscopic manual dissection (CMD). One part of the RNA was directly labelled and hybridised to GeneChips (HG-U133A, Affymetrix), the other part of the RNA was amplified according to the "Eberwine" protocol and was then hybridised to the microarrays. During unsupervised hierarchical clustering the samples were divided in groups regarding the RNA pre-treatment and 5.726 differentially expressed genes were identified. Using independent microarray data of 31 amplified vs. 24 non amplified RNA samples from colon carcinomas (stage UICC III) in a set of 50 predictive genes we validated the amplification bias. In conclusion microarray data resulting from different pre-processing regarding RNA pre-amplification can not be compared within one analysis.

Copyright ( 2009 Roland S. Croner et al. This is an open access article distributed under the Creative Commons Attribution License, which permits unrestricted use, distribution, and reproduction in any medium, provided the original work is properly cited.

\section{Introduction}

Microarray-based investigations of genome wide gene expression have become a popular method for the molecular characterisation of various tissue types. In molecular oncology prognosis-related genes could be identified concerning various cancer types [1-5]. Especially in colorectal carcinoma gene clusters related to metastasis, tumour recurrence or chemoradiation were described [4, 6-8]. Microarray analysis in most of these studies was not dependent on RNA amplification, as enough RNA could be isolated from the tumours. Whenever tissue is limited and a high-throughput analysis is in concern, amplification of RNA by in vitro transcription is essential. However, using amplification, one has to be sure that the RNA is amplified linear, meaning that gene expressions will be comparable between native and amplified RNA. This is necessary, as more and more data are generated with different methods, stored at the internet being available for the research community. Recently the limited comparability of gene expression profiles between studies using different techniques has been demonstrated [5]. However, there is an ongoing discussion if microarray data of non amplified and amplified RNA samples are comparable. The aim of our study was to evaluate to which extend (1) the microarray data based on amplified RNA are reproducible, (2) the expression data from amplified and native RNA are comparable, and (3) if tumour specific genes are affected by an amplification bias. 


\section{Material and Methods}

2.1. Patients and Experimental Procedure. Primary tumours of four patients with colorectal carcinomas stage UICC IV resected at the Department of Surgery at the FriedrichAlexander-University Erlangen-Nuremberg were chosen for the analysis. No patient received neoadjuvant treatment prior to surgery. By approval of the Ethical Committee of our University and by patient consent, conformity to the ethical guidelines for human research respecting the principles of the Declaration of Helsinki was provided. After tumour enrichment by cryotomy after manual dissection (CMD) RNA was isolated from each sample [9]. One part of the RNA of each sample was hybridized to the microarray without amplification; the other part underwent amplification prior to microarray hybridization (Figure 1). For validation purpose the microarray data of amplified RNA from 31 colon carcinoma samples stage UICC III versus the microarray data of not amplified RNA from 24 colon carcinoma samples were used. Patient selection, tissue workup, and amplification protocol were equally in each group.

2.2. Sample Workup and RNA Isolation. The tissue was inserted into a cryotube (Roth, Karlsruhe, Germany) together with Tissue-Tek (Zakura, Zoeterwoude, Netherlands) and immediately shock frozen in liquid nitrogen after surgery and stored at $-80^{\circ} \mathrm{C}$ until further workup. CMD was performed as recently described [9]. RNA isolation was performed in the same way from all four tissue samples using commercial kits (RNeasy-Kit, Qiagen, Hilden, Germany), following the manufacturers' protocol. Each sample was added to the Qiagen spin column, and centrifuged to bind the RNA to the matrix. The column was washed with the buffers provided in the kit, and the RNA was finally eluted with distilled $\mathrm{H}_{2} 0$. Within this procedure a DNAse (Qiagen, Hilden, Germany) digestion was included following the manufacturers' suggestion. RNA quality and quantity was determined by the "Lab on a Chip" method (Bioanalyzer 2100, Agilent Technologies, Palo Alto, USA) following the manufacturers' instructions [10]. A total of $50 \mathrm{ng}$ to $100 \mathrm{ng}$ of each RNA sample was loaded/well. The analyser allows for visual examination of both the $18 \mathrm{~S}$ and $28 \mathrm{~S}$ rRNA bands as measure of RNA integrity.

The $3^{\prime} / 5^{\prime}$-ratios for the housekeeping genes glycerinaldehyde-3-phosphatase (GAPDH) and B-actin supplied by the GeneChip were used as further parameters for RNA quality and to exclude partial degradation. A $3^{\prime} / 5^{\prime}$-ratio below the value of 3 was regarded as an indicator for good RNA quality according to the manufacturers' protocol (Affymetrix, Santa Clara, USA) [11].

2.3. RNA Amplification. Amplification of RNA was performed with the Message Amp aRNA kit (Ambion, Austin (Tx), USA) according to the manufacturers' instructions, using $200 \mathrm{ng}$ of total RNA for each sample. Briefly, first strand cDNA syntheses were primed with the T/Oligo $(\mathrm{dT})$ primer to synthesize cDNA with a $\mathrm{T} /$ promoter sequence

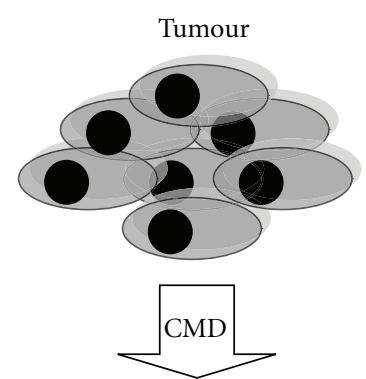

RNA isolation

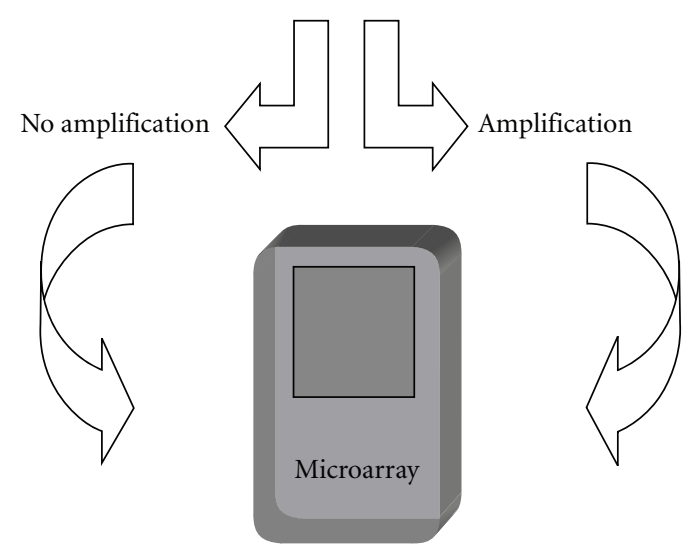

FIGURE 1: Experimental procedure. RNA was isolated from tumours after CMD; one part of the RNA underwent amplification and the other part was hybridized without preamplification to microarrays.

from the poly (A) tails of massages by reverse transcription. The second strand CDNA synthesis converted cDNA with the T7 promoter primer into double-stranded DNA (dsDNA) template for transcription. Following a cDNA purification step an in vitro transcription was done, generating multiple copies of aRNA from the double-stranded cDNA templates. Finally, in another purification step, unincorporated NTPs, salts, enzymes, and inorganic phosphate were removed. In a second round, the additional amplification of the RNA sample was achieved. Besides using different primers for the second round, the same reagents and methodology were used. During this second round the biotin labelling of the probe took place before the in vitro transcription step. Hereunto, for each sample, $3.75 \mu \mathrm{L}$ of $10 \mathrm{mM}$ biotin 11-CTP and $3.75 \mu \mathrm{L}$ of $10 \mathrm{mM}$ biotin-16-UTP were added and the probe dried in a vacuum centrifuge concentrator.

\subsection{Labelling of "Native" RNA and GeneChip Hybridization.} Biotin-labelled cRNA was generated by in vitro transcription as described previously and hybridized to the GeneChips (HG-U133A, Affymetrix) following the manufacturers' instructions. For first-strand cDNA synthesis, $9 \mu \mathrm{L}(13.5 \mu \mathrm{g})$ of total RNA were mixed with $1 \mu \mathrm{L}$ of a mixture of three polyadenylated control RNAs, $\quad 1 \mu \mathrm{L} \quad 100 \mu \mathrm{M} \quad$ T7-oligo-d(T)21-V primer $\quad\left(5^{\prime}-\right.$ G CATT AGCGGC CGCGAAA TTAATA CGACTCACT ATAGGGAGA(T)21V-3'), incubated at $70^{\circ} \mathrm{C}$ for $10 \mathrm{~min}$ and put on ice. Next, $4 \mu \mathrm{L}$ of $5 \mathrm{x}$ first strand buffer, $2 \mu \mathrm{L} 0.1 \mathrm{M}$ DTT and $1 \mu \mathrm{L} 10 \mathrm{mM}$ dNTPs were added and the reaction 
TABle 1: Pearson correlations of microarray signals and detection $P$-values between non amplified (NA) and amplified (PA) RNA samples from four colorectal carcinoma specimens. The RNA was isolated from identical samples and underwent either amplification or no amplification prior to microarray hybridization.

\begin{tabular}{lcc}
\hline Samples & Signals & Detection $P$-value \\
\hline 1 NA versus 1 PA & 0.91 & .81 \\
2 NA versus 2 PA & 0.89 & .75 \\
3 NA versus 3 PA & 0.86 & .79 \\
4 NA versus 4 PA & 0.91 & .81 \\
\hline
\end{tabular}

was preincubated at $42^{\circ} \mathrm{C}$ for $2 \mathrm{~min}$. Then $2 \mu \mathrm{L}(200 \mathrm{U})$ Superscript II (Life Technologies, Karlsruhe, Germany) were added and incubation continued at $42^{\circ} \mathrm{C}$ for 1 hour. For second strand synthesis, $30 \mu \mathrm{L}$ of $5 \mathrm{x}$ second strand buffer, $91 \mu \mathrm{L}$ of RNAse-free water, $3 \mathrm{~mL} 10 \mathrm{mM}$ dNTPs, $4 \mu \mathrm{L}$ (40 U) E. coli DNA polymerase I (Life Technologies), $1 \mu \mathrm{L}$ (12 U) E. coli ligase (TaKaRa Biomedical Europe, Gennevilliers, France), $1 \mu \mathrm{L}$ ( $2 \mathrm{U})$ RNAse $\mathrm{H}$ (TaKaRa) were added and the reaction was incubated at $16^{\circ} \mathrm{C}$ for 2 hours. Then, $2.5 \mathrm{~mL}$ $(10 \mathrm{U}) \mathrm{T} 4 \mathrm{DNA}$ polymerase I (TaKaRa) were added at $16^{\circ} \mathrm{C}$ for $5 \mathrm{~min}$. The reaction was stopped by adding $10 \mu \mathrm{L}$ $0.5 \mathrm{M}$ EDTA, the double-stranded cDNA was extracted with phenol/chloroform and the aqueous phase was recovered by phase lock gel separation (Eppendorf, Hamburg, Germany). After precipitation, the cDNA was restored in $12 \mu \mathrm{L}$ of RNAse-free water. Five microliters of ds cDNA were used to synthesize biotinylated cRNA using the BioArray High Yield Transcript Labeling Kit (Enzo Diagnostics, NY, USA). Labelled cRNA was purified using the RNeasy mini kit (Qiagen, Hilden, Germany). Fragmentation of cRNA, hybridization to GeneChips, washing and staining as well as scanning of the arrays in the Gene Array scanner (Agilent) were performed as recommended by the Affymetrix Gene Expression Analysis Technical Manual. Signal intensities and detection calls for statistical analysis and hierarchical clustering were determined using the GeneChip 5.0 software.

2.5. Statistics. Significance levels of microarray results between non amplified (NA) and amplified (PA) RNA samples were calculated using the Mann-Whitney U-test $(P<.05$, means differecially expressed). The average signal intensity of PA/NA was calculated as fold change (FC). Unsupervised and supervised hierarchical cluster analyses of all 22.215 probe sets (HG-U 133A, Affymetrix) were performed (Spotfire, Decision Site, Somerville, USA). Differences in signal intensity of microarray results between NA versus PA were analysed regarding sequence length and chromosomal localization. Pearson correlation of signals and detection $P$ values from microarray results between NA versus PA were investigated.

Moreover, validation of amplification bias was done for 22.215 gene expression values (HG-U133A, Affymetrix) for 31 amplified RNA samples of colon carcinoma samples versus 24 not amplified RNA samples of colon carcinoma samples, all stage UICC III. The Pearson correlation was calculated and the mean expression values and standard deviation $\left(\log _{2}\right)$ of 50 predictive genes for lymphatic metastasis recently described have been compared [12]. For validation purpose gene expression measures were computed with the Robust Multichip Average (RMA) method described in Irizarry et al. [12] and implemented in the R-function just RMA of the Bioconductor R package affy. The statistical analysis was performed with the open-source software R, Version 2.6.1.

\section{Results}

3.1. Comparability of Amplified and Non Amplified RNA. In the amplified test set $200 \mathrm{ng}$ of RNA was used as the starting yield. Two rounds of amplification of RNA resulted in sufficient amounts of cRNA with good quality for microarray hybridization. The correlation of the microarray signals between non amplified and amplified RNA reached 86\%$91 \%$. The detection $P$-values of the microarray data correlated in $75 \%-81 \%$ (Table 1). An unsupervised hierarchical cluster analysis including all 22.283 probe sets from the GeneChips separated all unamplified from the preamplified RNA samples (Figure 2). All samples were correctly classified regarding the method of RNA pretreatment. In the statistical analysis (Mann-Whitney U-test, $P<.05) 5.725$ significantly differentially expressed genes between non amplified and amplified RNA samples could be identified. In 1.182 probe sets of the microarray a significantly elevated signal intensity of amplified versus non amplified samples could be detected. In 4.543 probe sets significantly lower signal intensity between amplified versus non amplified RNA could be detected. The fold change (PA/NA) of the mean signals was between 8 (bicaudal-D (BICD) mRNA) and 13 (myosin I $\times \mathrm{b}$ (MYO9b) mRNA). Several ribosomal RNA (e.g., 18S rRNA gene) which were included on the microarrays as internal control could be detected with a fold change of 273 between amplified vs. non amplified samples. In 36\% RNA with increased FC and in 32\% RNA with a decreased FC had a sequence length between 1000-19000 bp. In 5\% RNA with increased FC and in 1\% RNA with a decreased FC had a sequence length $>300000 \mathrm{bp}$ (Figure 3(a)). Thirteen per cent of genes with an increased FC were located on chromosome $1 ; 10 \%$ on chromosome $17 ; 9 \%$ on chromosome 6 , and $8 \%$ on chromosome 2. Eleven per cent of genes with decreased FC were located on chromosome 19; 9\% were located on chromosome 2, chromosome 7 , and chromosome 12, and $8 \%$ on chromosome 16 (Figure $3(\mathrm{~b})$ ).

\subsection{Influence of RNA Amplification on Colorectal Cancer} Specific Genes. Various genes which have been recently described participating in carcinogenesis and tumour progression in colorectal carcinomas could be identified with significantly different signals between amplified and non amplified RNA samples (e.g., WNT3, APC, and VEGF). VEGFB had a decreased FC of -5 and the APC gene -4 . Several genes involved in the cell cycle (CDC5, CDC6, CDC2, CDC25C, CDC25A) were found with significantly 


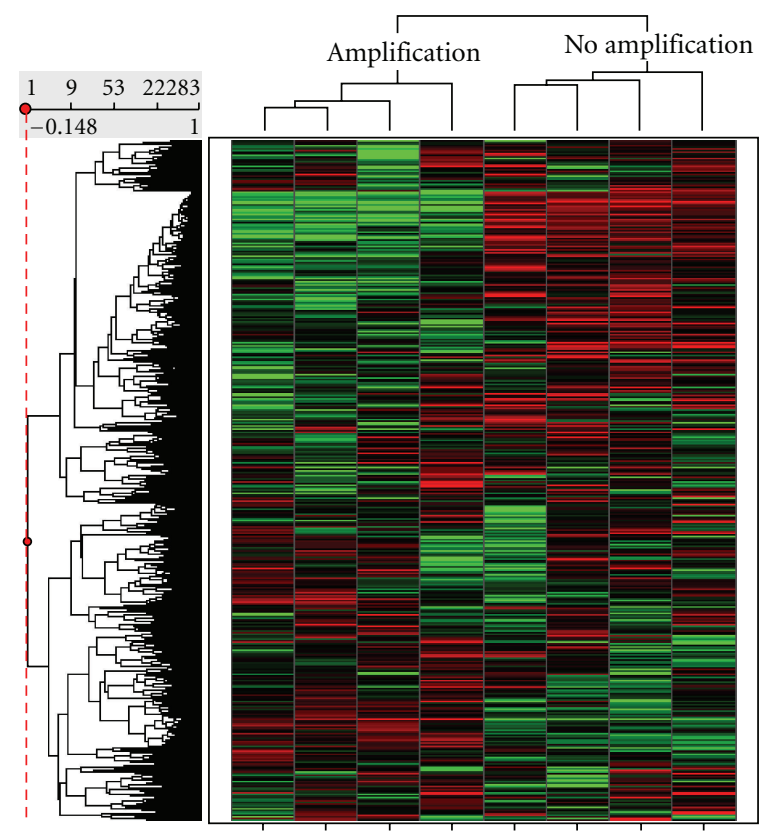

(a)

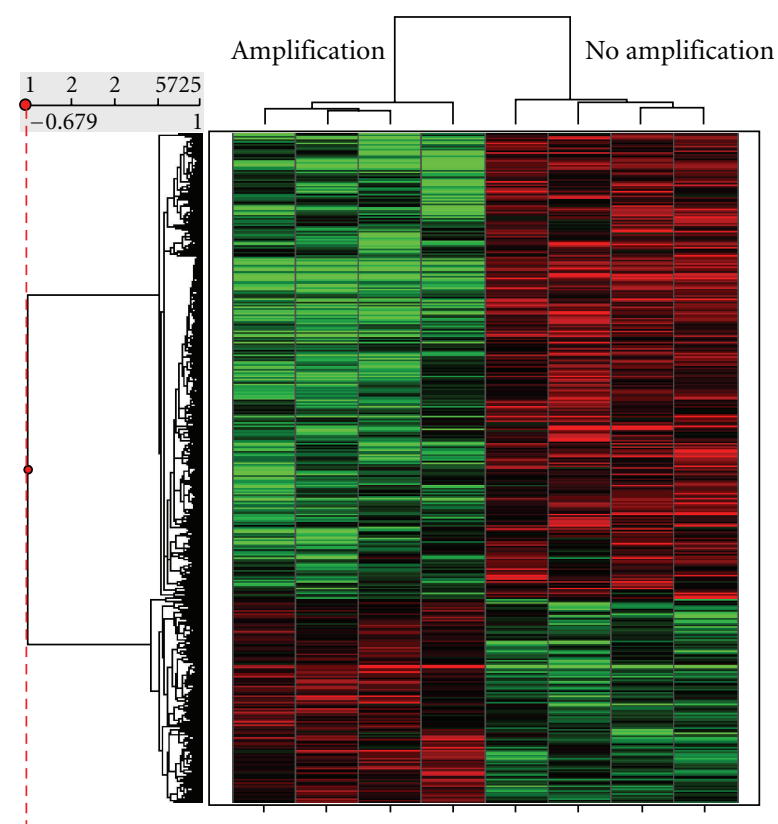

(b)

FIgURE 2: Unsupervised (a) and supervised (b) hierarchical cluster analysis of microarray results from non amplified and amplified RNA samples from colorectal carcinoma samples.

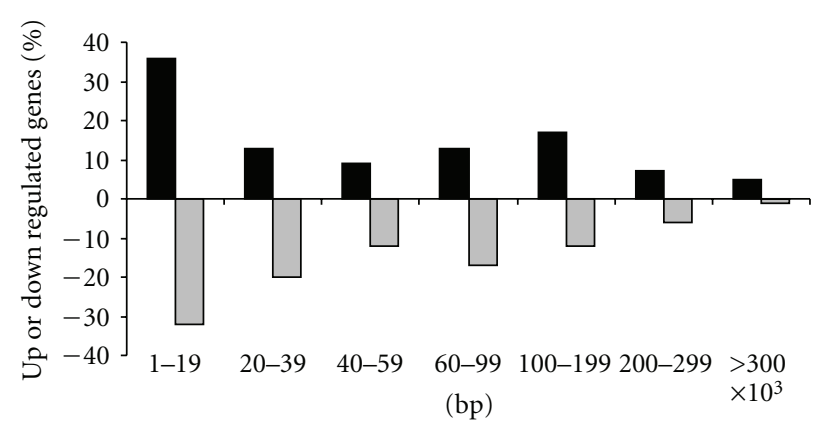

(a)

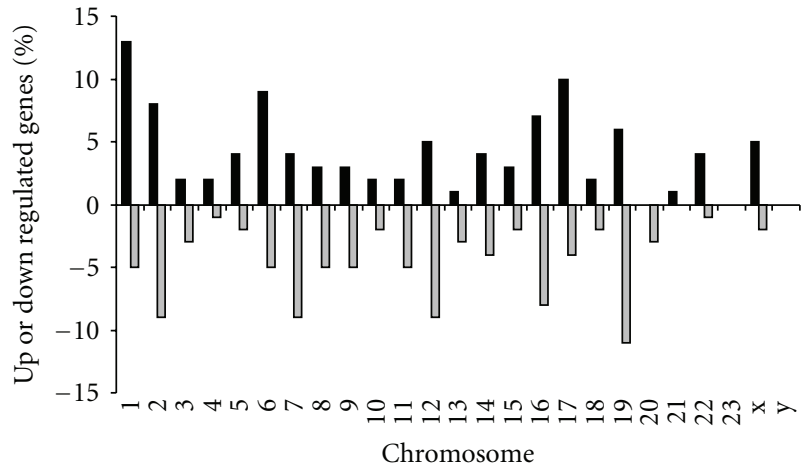

(b)

FIGURE 3: Differences in total gene expressions between non amplified (NA) versus amplified (PA) RNA, regarding (a) sequence length of genes and (b) chromosomal localization.

different microarray signals with an FC between 3 and -4 . Matrix metalloproteinases as MMP-11, MMP14, and MMP 15 showed decreased FC between -4 and -9 (Table 2).

3.3. Validation of Amplification Bias. The Spearman correlation of 22.115 probe sets (Affymetrix HG-U133A) between 31 amplified RNA samples versus 24 not amplified RNA samples of colon carcinomas stage UICC III was 0.8 (Figure 4). Comparing the mean microarray signals of 50 recently described genes predictive for lymphatic metastasis only in one case an equal value could be detected (210701_at). The standard deviation in this case was less high without RNA amplification. In most other genes substantially differences were identified (Table 3).

\section{Discussion}

Gene expression profiling has become an attractive tool for tissue typing and prognostic evaluations in cancer research. For colorectal carcinoma several gene profiles dividing healthy mucosa from tumours and for prognostic classification could be identified [5, 7, 12-15]. Nevertheless there is only a limited overlap in the described gene profiles in most of these studies [5]. One reason for this finding might be the fact that there is a brought variability of applied techniques used during the analysis. Regarding the methods of tissue handling and isolation, RNA preparation, and microarray hybridization, various distributive factors may influence the results. Especially, when only small amounts of tissue can be harvested or only limited amounts of tissue 
TABLE 2: Different gene expression values of cancer specific genes between non amplified (NA) and amplified (PA) RNA samples from colorectal carcinoma samples.

\begin{tabular}{|c|c|c|c|c|c|c|c|}
\hline Affy & $\mathrm{Gb}$ & Bases & Anotation & Avg. Signals NA & Avg. Signals PA & FC PA/NA & $P$ \\
\hline 221455_s_at & NM_030753 & 56038 & $\begin{array}{l}\text { Wingless-type } \\
\text { MMTV integration } \\
\text { site family, member } 3 \\
\text { (WNT3). }\end{array}$ & 20 & 78 & 4 & .04 \\
\hline 212447_at & AF161402 & 23,589 & $\begin{array}{l}\text { HSPC } 284 \text { mRNA, } \\
\text { partial cds. }\end{array}$ & 2480 & 9611 & 4 & .01 \\
\hline 201111_at & NM_001253 & 50,649 & $\begin{array}{l}\text { Brain cellular } \\
\text { apoptosis } \\
\text { susceptibility protein } \\
\text { (CSE1). }\end{array}$ & 2568 & 7431 & 3 & .01 \\
\hline 209056_s_at & NM_001253 & 62,329 & $\begin{array}{l}\text { CDC5 (cell division } \\
\text { cycle 5, S. pombe, } \\
\text { homolog)-like } \\
\text { (CDC5L). }\end{array}$ & 1399 & 3861 & 3 & .01 \\
\hline 206458_s_at & NM_024494 & 54,746 & $\begin{array}{l}\text { Wingless-type } \\
\text { MMTV integration } \\
\text { site family, member } \\
\text { 2B (WNT2B). }\end{array}$ & 72 & 177 & 2 & .01 \\
\hline 207149_at & L33477 & $1,102,757$ & $\begin{array}{l}\text { Br-cadherin mRNA, } \\
\text { complete cds. }\end{array}$ & 35 & 84 & 2 & .04 \\
\hline 204731_at & NM_003243 & 225,660 & $\begin{array}{l}\text { Transforming growth } \\
\text { factor, beta receptor } \\
\text { III (TGFBR3). }\end{array}$ & 602 & 1336 & 2 & .04 \\
\hline 219226_at & NM_016507 & 73,062 & $\begin{array}{l}\text { CDC2-related protein } \\
\text { kinase } 7 \text { (CrkRS). }\end{array}$ & 555 & 1131 & 2 & .01 \\
\hline 217366_at & Z37994 & 3620 & $\begin{array}{l}\text { Alpha E-catenin } \\
\text { pseudogene. }\end{array}$ & 30 & 6 & 2 & .04 \\
\hline 208504_x_at & NM_018931 & 3321 & $\begin{array}{l}\text { Protocadherin beta } 11 \\
(\text { PCDHB11). }\end{array}$ & 33 & 11 & 2 & .04 \\
\hline 201069_at & NM_004530 & 27,516 & $\begin{array}{l}\text { Matrix } \\
\text { metalloproteinase } 2 \\
(\text { MMP2). }\end{array}$ & 1528 & 887 & -2 & .04 \\
\hline 203968_s_at & NM_001254 & 15,268 & $\begin{array}{l}\text { Cell division cycle } 6 \\
\text { (CDC6). }\end{array}$ & 624 & 338 & -2 & .01 \\
\hline 203918_at & NM_002587 & 25,296 & $\begin{array}{l}\text { Protocadherin } 1 \\
(\mathrm{PCDH} 1) .\end{array}$ & 544 & 290 & -2 & .04 \\
\hline 208756_at & U36764 & 9235 & $\begin{array}{l}\text { TGF-beta receptor } \\
\text { interacting protein } 1 .\end{array}$ & 4451 & 2355 & -2 & .01 \\
\hline 210838_s_at & L17075 & 15,944 & $\begin{array}{l}\text { TGF-b superfamily } \\
\text { receptor type I. }\end{array}$ & 277 & 127 & -2 & .01 \\
\hline 206943_at & NM_004612 & 49,063 & $\begin{array}{l}\text { Transforming growth } \\
\text { factor, beta receptor I } \\
\text { (TGFBR1). }\end{array}$ & 331 & 150 & -2 & .01 \\
\hline 212143_s_at & BF340228 & 9028 & $\begin{array}{l}\text { Insulin-like growth } \\
\text { factor binding protein } \\
3 \text {. }\end{array}$ & 1192 & 462 & -3 & .01 \\
\hline 202039_at & NM_004740 & 2089 & $\begin{array}{l}\text { TGFB1-induced } \\
\text { antiapoptotic factor } 1 \\
\text { (TIAF1). }\end{array}$ & 1000 & 371 & -3 & .01 \\
\hline
\end{tabular}


TABle 2: Continued.

\begin{tabular}{|c|c|c|c|c|c|c|c|}
\hline Affy & $\mathrm{Gb}$ & Bases & Anotation & Avg. Signals NA & Avg. Signals PA & FC PA/NA & $P$ \\
\hline 203214_x_at & NM_001786 & 18927 & $\begin{array}{l}\text { Cell division cycle } 2 \text {, } \\
\text { G1 to } \mathrm{S} \text { and } \mathrm{G} 2 \text { to } \mathrm{M} \\
\text { (CDC2). }\end{array}$ & 3181 & 1174 & -3 & .01 \\
\hline 160020_at & Z48481 & 11,011 & $\begin{array}{l}\text { Membrane-type } \\
\text { matrix } \\
\text { metalloproteinase } 1 \\
\text { (MMP1). }\end{array}$ & 1258 & 437 & -3 & .01 \\
\hline 217010_s_at & AF277724 & 46,558 & $\begin{array}{l}\text { Cell division cycle } \\
\text { 25C splice variant } 3 \\
\text { (CDC25C). }\end{array}$ & 211 & 61 & -3 & .01 \\
\hline 204696_s_at & NM_001789 & 31,134 & $\begin{array}{l}\text { Cell division cycle } \\
25 \mathrm{~A}(\mathrm{CDC} 25 \mathrm{~A}) .\end{array}$ & 123 & 34 & -4 & .01 \\
\hline 203527_s_at & NM_000038 & 108,353 & $\begin{array}{l}\text { Adenomatosis } \\
\text { polyposis coli (APC). }\end{array}$ & 85 & 23 & -4 & .01 \\
\hline 210287_s_at & U01134 & 192,877 & $\begin{array}{l}\text { Soluble vascular } \\
\text { endothelial cell } \\
\text { growth factor } \\
\text { receptor (sflt). }\end{array}$ & 143 & 37 & -4 & .01 \\
\hline 203878_s_at & NM_005940 & 11,468 & $\begin{array}{l}\text { Matrix } \\
\text { metalloproteinase } 11 \\
\text { (stromelysin 3) } \\
\text { (MMP11). }\end{array}$ & 1546 & 400 & -4 & .01 \\
\hline 203365_s_at & NM_002428 & 21,524 & $\begin{array}{l}\text { Matrix } \\
\text { metalloproteinase } 15 \\
\text { (membrane-inserted) } \\
\text { (MMP15). }\end{array}$ & 388 & 93 & -4 & .04 \\
\hline 203683_s_at & NM_003377 & 3994 & $\begin{array}{l}\text { Vascular endothelial } \\
\text { growth factor B } \\
\text { (VEGFB). }\end{array}$ & 422 & 78 & -5 & .01 \\
\hline 217279_x_at & X83535 & 11,011 & $\begin{array}{l}\text { Membrane-type } \\
\text { matrix } \\
\text { Metalloproteinase } \\
\text { (MMP14). }\end{array}$ & 244 & 27 & -9 & .01 \\
\hline 204380_s_at & M58051 & 15,565 & $\begin{array}{l}\text { Fibroblast growth } \\
\text { factor receptor } \\
\text { (FGFR3). }\end{array}$ & 224 & 25 & -9 & .01 \\
\hline 207334_s_at & NM_003242 & 87,641 & $\begin{array}{l}\text { Transforming growth } \\
\text { factor, beta receptor II } \\
\text { (TGFBR2). }\end{array}$ & 323 & 15 & -16 & .01 \\
\hline
\end{tabular}

are available, the yield of RNA might not be sufficient for microarray hybridization. Preprocessing of the RNA by amplification becomes indispensable. Whether samples of amplified RNA can be compared to samples with non amplified RNA is still discussed controversially. For the amplified probes, we used the linear amplification technique which is based on a double-stranded cDNA synthesis with an oligodT primer coupled to the T7 RNA polymerase promoter followed by an in vitro transcription into aRNA by T7 RNA polymerase [16]. This is an established technique used for RNA amplification procedures during microarray experiments [17-19]. During two rounds of amplification enough RNA in sufficient quality could be generated for microarray hybridization which supports the reliability of the method. The Affymetrix (Santa Clara, USA) GeneChip technology provides standardized protocols for microarray procedures on a commercial platform which is frequently used in gene expression profiling regarding colorectal tumours $[4,14$, 20-24]. Using unsupervised hierarchical cluster analysis of our microarray results we observed a separation of two groups respecting the RNA pretreatment. We identified 5.725 significantly differentially expressed genes between non amplified and amplified RNA samples. As amplified and non amplified RNA referred to the same samples no separation in clusters should have been occurred. The cluster results and the identification of significantly different expressed 
TABLE 3: Comparison of mean signals and standard deviation (sdv) of genes which were recently described as predictive for lymphatic metastasis in colorectal carcinomas [12], between 31 amplified RNA samples of colon carcinomas and 24 RNA samples of colon carcinomas not amplified prior to microarray hybridization.

\begin{tabular}{|c|c|c|c|c|c|c|c|c|}
\hline \multicolumn{5}{|l|}{ Group } & \multicolumn{2}{|c|}{ Colon carcinoma } & \multicolumn{2}{|c|}{ Colon carcinoma } \\
\hline Samples; $\mathrm{n}$ & & & & & \multicolumn{2}{|c|}{31} & \multicolumn{2}{|c|}{24} \\
\hline Stage UICC & & & & & \multicolumn{2}{|c|}{ III } & \multicolumn{2}{|c|}{ III } \\
\hline Amplified & & & & & \multicolumn{2}{|c|}{ yes } & \multicolumn{2}{|c|}{ no } \\
\hline ProbeSet ID & $\mathrm{gb}$ & Gene & Bases & $\begin{array}{c}\text { fold change } \log _{2} \\
\text { mean amplified } \\
\text { versus non } \\
\text { amplified }\end{array}$ & $\log _{2}$ mean & $\log _{2} \mathrm{sdev}$ & $\log _{2}$ mean & $\log _{2}$ sdev \\
\hline 205433_at & NM_000055 & $\mathrm{BCHE}$ & 64562 & 1.05 & 4.36 & 0.71 & 4.16 & 0.21 \\
\hline 211044_at & BC006333 & TRIM14 & 49,926 & 0.8 & 3.37 & 0.18 & 4.22 & 0.24 \\
\hline 37547_at & U85995 & PTHB1 & 476,529 & 1.32 & 5.63 & 0.61 & 4.25 & 0.17 \\
\hline 215973_at & AF036973 & HCG4P6 & 1060 & 0.89 & 4.07 & 0.36 & 4.56 & 0.21 \\
\hline 214376_at & AI263044 & EST & 363 & 0.99 & 4.53 & 0.36 & 4.55 & 0.14 \\
\hline 216489_at & AB046836 & TRPM3 & 911,872 & 0.75 & 3.46 & 0.16 & 4.62 & 0.2 \\
\hline 211201_at & M95489 & FSHR & 192,237 & 0.76 & 3.55 & 0.21 & 4.65 & 0.16 \\
\hline 214068_at & AF070610 & BEAN & 56,130 & 0.74 & 3.45 & 0.41 & 4.66 & 0.21 \\
\hline 216063_at & N55205 & HBBP1 & 1742 & 0.79 & 3.75 & 0.21 & 4.72 & 0.24 \\
\hline 219791_s_at & NM_024748 & FLJ11539 & 11,373 & 0.77 & 3.67 & 0.43 & 4.77 & 0.2 \\
\hline 209353_s_at & BC001205 & SIN3B & 50,947 & 0.92 & 4.37 & 0.23 & 4.77 & 0.29 \\
\hline 211381_x_at & AF168617 & SPAG11 & 15,917 & 0.76 & 3.63 & 0.22 & 4.78 & 0.35 \\
\hline 207021_at & NM_007009 & $\mathrm{ZPBP}$ & 155,788 & 0.74 & 3.57 & 0.2 & 4.85 & 0.17 \\
\hline 220227_at & NM_024883 & $\mathrm{CDH} 4$ & 684,743 & 0.74 & 3.77 & 0.19 & 5.12 & 0.38 \\
\hline 210701_at & D85939 & CFDP1 & 139,780 & 1 & 5.12 & 0.42 & 5.12 & 0.22 \\
\hline 220156_at & NM_024593 & EFCAB1 & 11,825 & 0.76 & 4.04 & 0.17 & 5.32 & 0.28 \\
\hline 209883_at & AF288389 & GLT25D2 & 101,898 & 0.89 & 4.67 & 0.77 & 5.25 & 0.19 \\
\hline 207031_at & NM_001189 & BAPX1 & 3661 & 1.04 & 5.54 & 0.67 & 5.32 & 0.29 \\
\hline 206885_x_at & NM_022559 & GH1 & 1636 & 0.76 & 4.14 & 0.27 & 5.47 & 0.25 \\
\hline 212963_at & BF968960 & TM2D1 & 44,379 & 0.83 & 4.6 & 0.41 & 5.55 & 0.27 \\
\hline 207897_at & NM_001883 & CRHR2 & 46,857 & 0.81 & 4.59 & 0.16 & 5.67 & 0.32 \\
\hline 222083_at & AW024233 & GLYAT & 23,218 & 0.64 & 3.69 & 0.21 & 5.72 & 0.37 \\
\hline 214149_s_at & AI252582 & ATP6V0E & 51,138 & 0.86 & 5.07 & 0.49 & 5.87 & 0.58 \\
\hline 220332_at & NM_006580 & CLDN16 & 22,493 & 0.82 & 4.71 & 0.25 & 5.75 & 0.21 \\
\hline 220944_at & NM_020393 & PGLYRP4 & 18,721 & 0.78 & 4.57 & 0.27 & 5.84 & 0.52 \\
\hline 219170_at & NM_024333 & FSD1 & 19,171 & 0.91 & 5.35 & 0.24 & 5.9 & 0.36 \\
\hline 221113_s_at & NM_016087 & WNT16 & 15,738 & 1.03 & 6.15 & 0.17 & 5.95 & 0.28 \\
\hline 221431_s_at & NM_030959 & OR12D3 & 948 & 0.68 & 4.08 & 0.23 & 6.03 & 0.31 \\
\hline 207936_x_at & NM_006604 & RFPL3 & 6277 & 0.64 & 3.96 & 0.36 & 6.16 & 0.47 \\
\hline 204303_s_at & NM_014772 & KIAA0427 & 324,158 & 0.99 & 6.01 & 0.31 & 6.09 & 0.17 \\
\hline 210272_at & M29873 & CYP2B7P1 & 26,394 & 0.74 & 4.69 & 0.23 & 6.35 & 0.38 \\
\hline 207984_s_at & NM_005374 & MPP2 & 32,387 & 0.64 & 4.07 & 0.25 & 6.36 & 0.26 \\
\hline 208227_x_at & NM_021721 & ADAM22 & 262,753 & 0.69 & 4.55 & 0.31 & 6.56 & 0.35 \\
\hline 213847_at & NM_006262 & $\mathrm{PRPH}$ & 4997 & 0.84 & 5.63 & 0.33 & 6.71 & 0.42 \\
\hline 215544_s_at & AL121891 & UBOX5 & 14,320 & 0.85 & 5.83 & 0.23 & 6.85 & 0.31 \\
\hline 336_at & D38081 & TBXA2R & 12,155 & 0.74 & 5.03 & 0.24 & 6.84 & 0.28 \\
\hline 209402_s_at & AF047338 & SLC12A4 & 24,296 & 1 & 6.97 & 0.26 & 7 & 0.25 \\
\hline 221629_x_at & AF151022 & LOC51236 & 2948 & 0.83 & 6.04 & 0.58 & 7.29 & 0.5 \\
\hline 219071_x_at & NM_016458 & C8orf30A & 2948 & 1.03 & 8.12 & 0.71 & 7.92 & 0.52 \\
\hline 56829_at & H61826 & NIBP & 726,091 & 0.82 & 6.83 & 0.27 & 8.29 & 0.3 \\
\hline 205835_s_at & AW975818 & YTHDC2 & 81,572 & 0.9 & 4.11 & 0.17 & 4.59 & 0.19 \\
\hline
\end{tabular}


Table 3: Continued.

\begin{tabular}{|c|c|c|c|c|c|c|c|c|}
\hline \multicolumn{5}{|l|}{ Group } & \multicolumn{2}{|c|}{ Colon carcinoma } & \multicolumn{2}{|c|}{ Colon carcinoma } \\
\hline Samples; $\mathrm{n}$ & & & & & \multicolumn{2}{|c|}{31} & \multicolumn{2}{|c|}{24} \\
\hline Stage UICC & & & & & \multicolumn{2}{|c|}{ III } & \multicolumn{2}{|c|}{ III } \\
\hline Amplified & & & & & \multicolumn{2}{|c|}{ yes } & \multicolumn{2}{|c|}{ no } \\
\hline 213254_at & N64803 & TNRC6B & 290,992 & 0.93 & 6.15 & 0.23 & 6.65 & 0.38 \\
\hline 34764_at & D21851 & LARS2 & 160,261 & 1.01 & 7.13 & 0.63 & 7.04 & 0.51 \\
\hline 209711_at & N80922 & SLC35D1 & 50,402 & 1.32 & 10.2 & 0.52 & 7.73 & 0.45 \\
\hline 203073_at & NM_007357 & COG2 & 51,491 & 1 & 8.11 & 0.51 & 8.07 & 0.3 \\
\hline 209174_s_at & BC000978 & FLJ20259 & 64,363 & 1.07 & 8.71 & 0.32 & 8.17 & 0.25 \\
\hline 221884_at & BE466525 & EVI1 & 64,236 & 1.25 & 10.56 & 0.66 & 8.46 & 0.46 \\
\hline 218160_at & NM_014222 & NDUFA8 & 15,762 & 1.22 & 11.3 & 0.38 & 9.24 & 0.47 \\
\hline 201386_s_at & AF279891 & DHX15 & 57,098 & 1.08 & 10.44 & 0.66 & 9.64 & 0.52 \\
\hline 202753_at & NM_014814 & PSMD6 & 13,281 & 1.14 & 11.46 & 0.44 & 10.03 & 0.46 \\
\hline
\end{tabular}

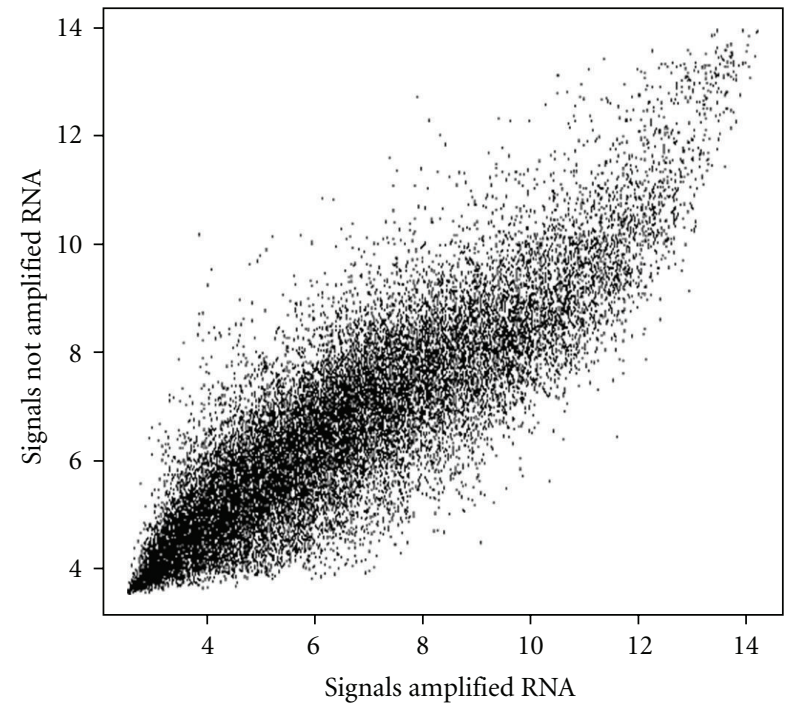

Figure 4: Comparison of mean signals (HG-U 133A, Affymetrix) between RNA samples of 31 colon carcinomas amplified and 24 RNA samples of colon carcinomas not amplified prior to microarray hybridization.

genes demonstrate an amplification bias between native and amplified RNA. The correlation of microarray signal NA versus PA was between $86-91 \%$. This amplification bias could be validated in a cohort of 55 RNA samples either amplified or not amplified from colon carcinoma samples (stage UICC III). The correlation of 22.115 probe set signals did reached only $80 \%$ and the comparison of 50 genes involved in lymphatic metastasis varied substantially. If the same labelled cRNA is hybridized twice to microarrays the correlation of signals is $99 \%$. When two cRNA samples are generated from the same mRNA and hybridized to microarrays, the correlation of signals is about $99 \%$ as well. Signal correlations of $97 \%$ were reached with two separate RNA isolations and microarray hybridizations of one and the same tumour probe (data not published). Behind these findings, the identified differences between amplified and non amplified RNA are relevant. Analysing the reasons for these findings we detected that sequences with a length of bp 1000-19000 are mainly affected by differential signal intensity. This may be explained due to the more frequent amplification of shorter transcripts which may be dependent on the amount of amplification rounds. A connection of sequences located on specific chromosomes could not be identified. These findings are supported by previous studies which identified a correlation between amplification rounds and comparability between native and amplified RNA [18]. The detected alterations during RNA amplification are important, because several genes of interest involved in carcinogenesis (e.g., APC, VEGF) and tumour progression (e.g., CDC2, MMPs) were affected. When amplified and non amplified RNA are compared in the same microarray study false positive results might occur. Therefore, amplified and non amplified RNA should not be compared during microarray investigations. These findings have already been suspected previously, but have not been demonstrated in detail so far $[18,19]$.

\section{Conclusion}

Amplification of RNA by the T7-IVT is an elegant method to generate RNA in good quality and sufficient yield for microarray hybridization from as less as $200 \mathrm{ng}$ of starting RNA. Nevertheless during amplification alterations occur which lead to an amplification bias compared to non amplified RNA. For this reason the microarray results of amplified and non amplified RNA samples should not be compared within the same study.

\section{Acknowledgments}

This study was sponsored by the German Federal Ministry for Education and Science (BMBF) and the Interdisciplinary Centre for Clinical Research (IZKF) of the University Erlangen-Nuremberg. We thank Dr. Ralph Wirtz from 
Siemens Healthcare Diagnostics (Germany) for providing microarray data from amplified RNA samples of colon carcinomas. R. S. Croner and B. Lausen contributed equally to this work.

\section{References}

[1] J. M. Bueno-de-Mesquita, W. H. van Harten, V. P. Retel, et al., "Use of 70-gene signature to predict prognosis of patients with node-negative breast cancer: a prospective community-based feasibility study (RASTER)," Lancet Oncology, vol. 8, no. 12, pp. 1079-1087, 2007.

[2] S.-Y. Kim, J.-H. Kim, H.-S. Lee, et al., "Meta- and gene set analysis of stomach cancer gene expression data," Molecules and Cells, vol. 24, no. 2, pp. 200-209, 2007.

[3] D. M. Greenawalt, C. Duong, G. K. Smyth, et al., "Gene expression profiling of esophageal cancer: comparative analysis of Barrett's esophagus, adenocarcinoma, and squamous cell carcinoma," International Journal of Cancer, vol. 120, no. 9, pp. 1914-1921, 2007.

[4] R. S. Croner, A. Peters, W. M. Brueckl, et al., "Microarray versus conventional prediction of lymph node metastasis in colorectal carcinoma," Cancer, vol. 104, no. 2, pp. 395-404, 2005.

[5] R. S. Croner, T. Foertsch, W. M. Brueckl, et al., "Common denominator genes that distinguish colorectal carcinoma from normal mucosa," International Journal of Colorectal Disease, vol. 20, no. 4, pp. 353-362, 2005.

[6] B. M. Ghadimi, M. Grade, M. J. Difilippantonio, et al., "Effectiveness of gene expression profiling for response prediction of rectal adenocarcinomas to preoperative chemoradiotherapy," Journal of Clinical Oncology, vol. 23, no. 9, pp. 1826-1838, 2005.

[7] C. M. Frederiksen, S. Knudsen, S. Laurberg, and T. F. Ørntoft, "Classification of Dukes' B and C colorectal cancers using expression arrays," Journal of Cancer Research and Clinical Oncology, vol. 129, no. 5, pp. 263-271, 2003.

[8] Y. Wang, T. Jatkoe, Y. Zhang, et al., "Gene expression profiles and molecular markers to predict recurrence of Dukes' B colon cancer," Journal of Clinical Oncology, vol. 22, no. 9, pp. 15641571, 2004.

[9] R. S. Croner, K. Guenther, T. Foertsch, et al., "Tissue preparation for gene expression profiling of colorectal carinoma: three alternatives to laser microdissection with preamplification," Journal of Laboratory and Clinical Medicine, vol. 143, no. 6, pp. 344-351, 2004.

[10] I. Nachamkin, N. J. Panaro, M. Li, et al., "Agilent 2100 bioanalyzer for restriction fragment length polymorphism analysis of the Campylobacter jejuni flagellin gene," Journal of Clinical Microbiology, vol. 39, no. 2, pp. 754-757, 2001.

[11] L. L. Hsiao, F. Dangond, T. Yoshida, et al., "A compendium of gene expression in normal human tissues," Physiol Genomics, vol. 7, no. 2, pp. 97-104, 2001.

[12] R. S. Croner, T. Förtsch, W. M. Brückl, et al., "Molecular signature for lymphatic metastasis in colorectal carcinomas," Annals of Surgery, vol. 247, no. 5, pp. 803-810, 2008.

[13] D. A. Notterman, U. Alon, A. J. Sierk, and A. J. Levine, "Transcriptional gene expression profiles of colorectal adenoma, adenocarcinoma, and normal tissue examined by oligonucleotide arrays," Cancer Research, vol. 61, no. 7, pp. 3124-3130, 2001.
[14] J. Groene, U. Mansmann, R. Meister, et al., "Transcriptional census of 36 microdissected colorectal cancers yields a gene signature to distinguish UICC II and III," International Journal of Cancer, vol. 119, no. 8, pp. 1829-1836, 2006.

[15] M. Grade, P. Hormann, S. Becker, et al., "Gene expression profiling reveals a massive, aneuploidy-dependent transcriptional deregulation and distinct differences between lymph nodenegative and lymph node-positive colon carcinomas," Cancer Research, vol. 67, no. 1, pp. 41-56, 2007.

[16] R. N. Van Gelder, M. E. von Zastrow, A. Yool, W. C. Dement, J. D. Barchas, and J. H. Eberwine, "Amplified RNA synthesized from limited quantities of heterogeneous cDNA," Proceedings of the National Academy of Sciences of the United States of America, vol. 87, no. 5, pp. 1663-1667, 1990.

[17] J. Wadenbäck, D. H. Clapham, D. Craig, et al., "Comparison of standard exponential and linear techniques to amplify small cDNA samples for microarrays," BMC Genomics, vol. 6, no. 1, article 61, 2005.

[18] J. Wilhelm, J. P. Muyal, J. Best, et al., "Systematic comparison of the T7-IVT and SMART-based RNA preamplification techniques for DNA microarray experiments," Clinical Chemistry, vol. 52, no. 6, pp. 1161-1167, 2006.

[19] J. Schneider, A. Buneß, W. Huber, et al., "Systematic analysis of T7 RNA polymerase based in vitro linear RNA amplification for use in microarray experiments," BMC Genomics, vol. 5, no. 1, article 29, 2004.

[20] D. A. Notterman, U. Alon, A. J. Sierk, and A. J. Levine, "Transcriptional gene expression profiles of colorectal adenoma, adenocarcinoma, and normal tissue examined by oligonucleotide arrays," Cancer Research, vol. 61, no. 7, pp. 3124-3130, 2001.

[21] W. M. Brueckl, W. G. Ballhausen, T. Förtsch, et al., "Genetic testing for germline mutations of the APC gene in patients with apparently sporadic desmoid tumors but a family history of colorectal carcinoma," Diseases of the Colon and Rectum, vol. 48, no. 6, pp. 1275-1281, 2005.

[22] W. H. Gmeiner, G. M. Hellmann, and P. Shen, "Tissuedependent and -independent gene expression changes in metastatic colon cancer," Oncology Reports, vol. 19, no. 1, pp. 245-251, 2008.

[23] A. H. Wiese, J. Auer, S. Lassmann, et al., "Identification of gene signatures for invasive colorectal tumor cells," Cancer Detection and Prevention, vol. 31, no. 4, pp. 282-295, 2007.

[24] Y.-H. Lin, J. Friederichs, M. A. Black, et al., "Multiple gene expression classifiers from different array platforms predict poor prognosis of colorectal cancer," Clinical Cancer Research, vol. 13, no. 2, part 1, pp. 498-507, 2007. 

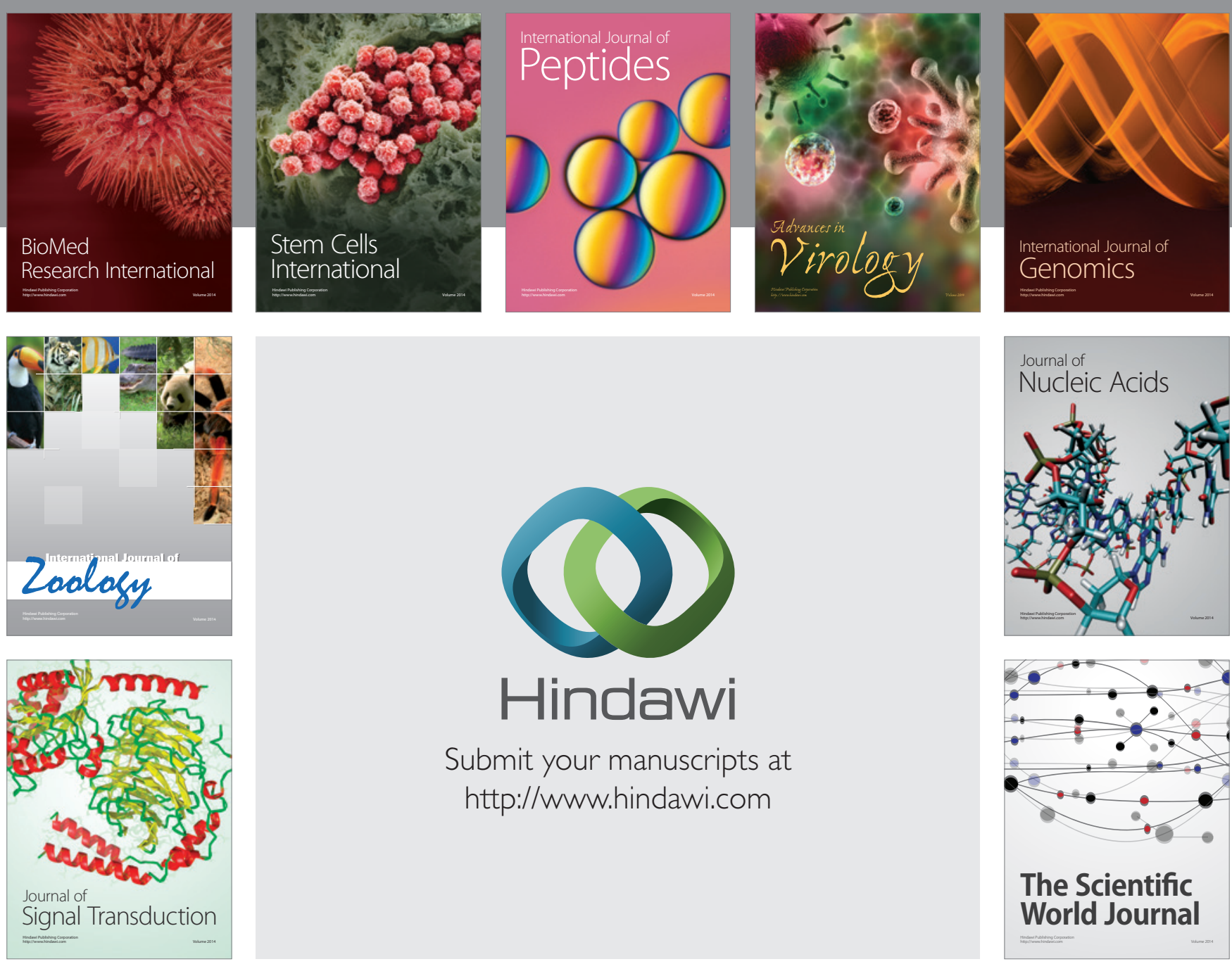

Submit your manuscripts at

http://www.hindawi.com
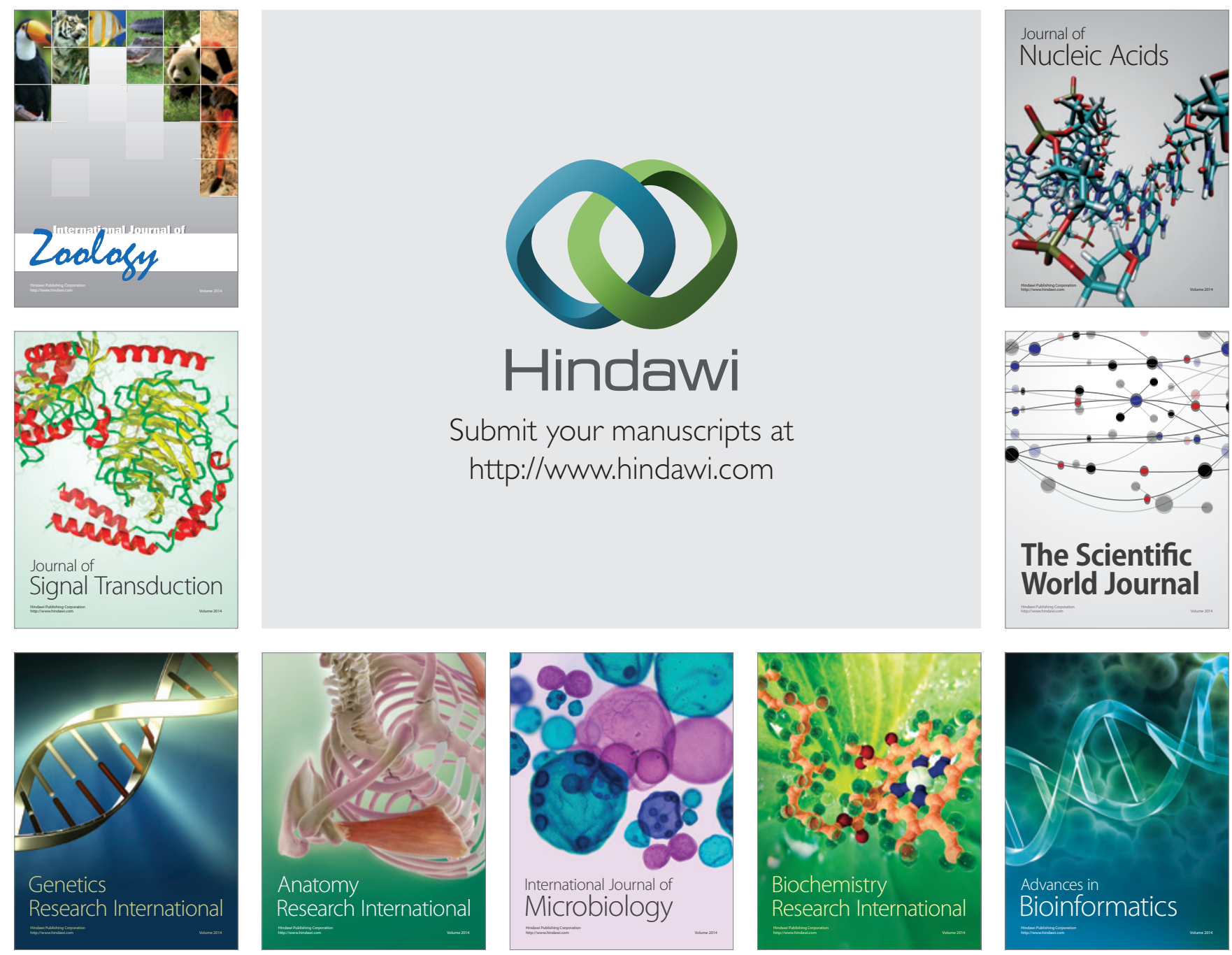

The Scientific World Journal
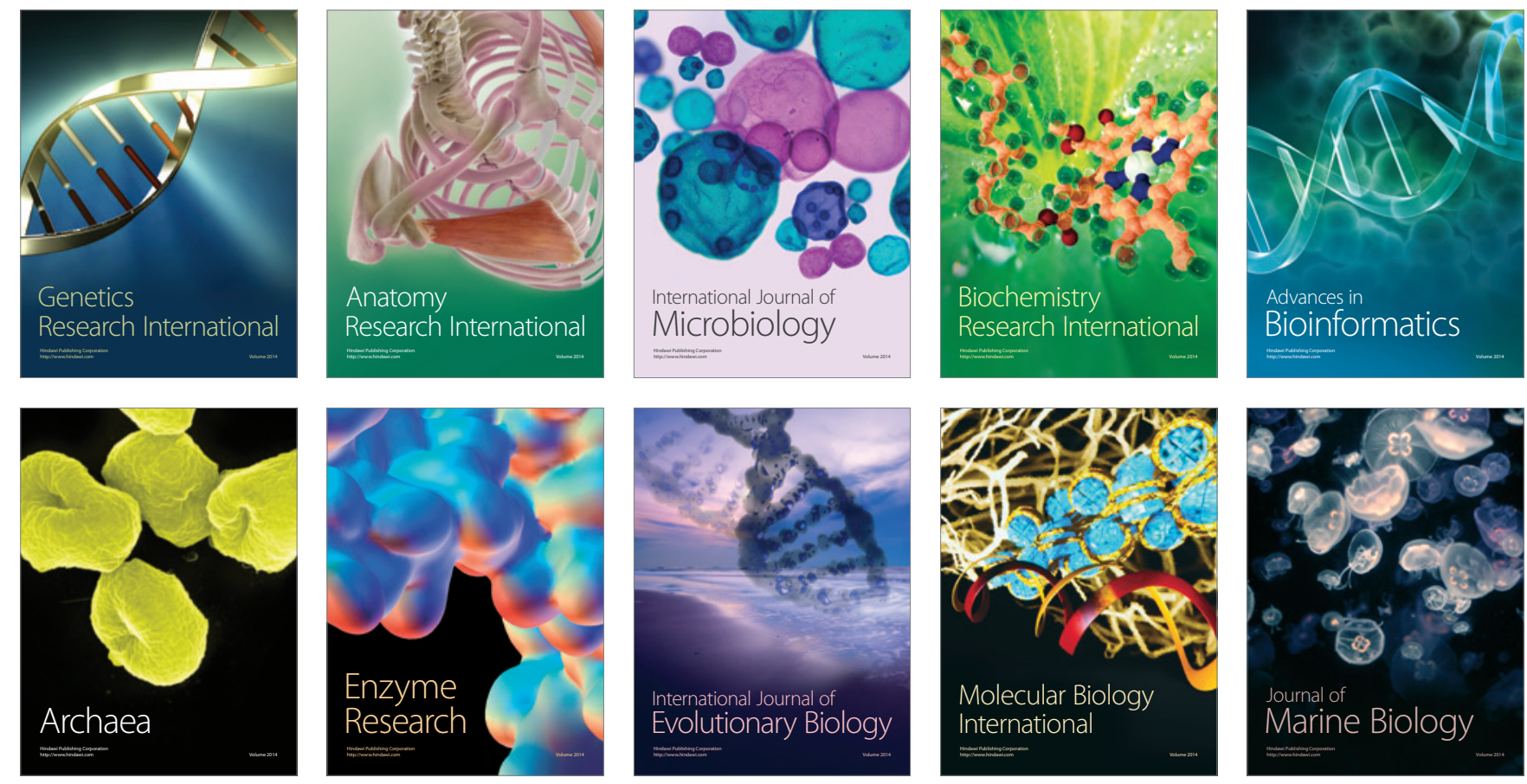